\title{
Intracerebral haemorrhage in Down syndrome: protected or
}

\section{predisposed? [version 1; peer review: 2 approved]}

\section{Lewis Buss ${ }^{1,5}$, Elizabeth Fisher ${ }^{2,5}$, John Hardy²,5, Dean Nizetic ${ }^{3-5}$, Jurgen Groet ${ }^{4,5}$, Laura Pulford2,5, André Strydom ${ }^{1,5}$}

\author{
${ }^{1}$ Division of Psychiatry, University College London, London, UK \\ 2Institute of Neurology, University College London, London, UK \\ ${ }^{3}$ Lee Kong Chian School of Medicine, Nanyang Technological University, Singapore, Singapore \\ ${ }^{4}$ Blizard Institute, Barts and the London School of Medicine, Queen Mary, University of London, London, UK \\ ${ }^{5}$ London Down Syndrome (LonDownS) Consortium, University College London, London, UK
}

V1 First published: 12 May 2016, 5(F1000 Faculty Rev):876
https://doi.org/10.12688/f1000research.7819.1

Latest published: 12 May 2016, 5(F1000 Faculty Rev):876

https://doi.org/10.12688/f1000research.7819.1

\section{Open Peer Review
Approval Status
version 1
12 May 2016
Faculty Reviews are review articles written by the
prestigious Members of Faculty Opinions. The
articles are commissioned and peer reviewed
before publication to ensure that the final,
published version is comprehensive and
accessible. The reviewers who approved the final
version are listed with their names and
affiliations.
Any...........................................................................
1. Ira Lott, University of California, Irvine, USA
2. Juan Fortea, Hospital de la Santa Creu i Sant
Pau, Barcelona, Spain \\ Open Peer Review
Approval Status
version 1
12 May 2016
Faculty Reviews are review articles written by the
prestigious Members of Faculty Opinions. The
articles are commissioned and peer reviewed
before publication to ensure that the final,
published version is comprehensive and
accessible. The reviewers who approved the final
version are listed with their names and
affiliations.
Any...........................................................................
1. Ira Lott, University of California, Irvine, USA
2. Juan Fortea, Hospital de la Santa Creu i Sant
Pau, Barcelona, Spain

version 1
12 May 2016
Faculty Reviews are review articles written by the
prestigious Members of Faculty Opinions. The
articles are commissioned and peer reviewed
before publication to ensure that the final,
published version is comprehensive and
accessible. The reviewers who approved the final
version are listed with their names and
affiliations.
..............................................................................
1. Ira Lott, University of California, Irvine, USA
2. Juan Fortea, Hospital de la Santa Creu i Sant
Pau, Barcelona, Spain
Any comments on the article can be found at the
end of the article.

Keywords

Intracerebral haemorrhage, Down syndrome, trisomy , Alzheimer's

disease, Cerebral amyloid angiopathy

\begin{abstract}
Down syndrome (DS), which arises from trisomy of chromosome 21, is associated with deposition of large amounts of amyloid within the central nervous system. Amyloid accumulates in two compartments: as plaques within the brain parenchyma and in vessel walls of the cerebral microvasculature. The parenchymal plaque amyloid is thought to result in an early onset

Alzheimer's disease (AD) dementia, a phenomenon so common amongst people with DS that it could be considered a defining feature of the condition. The amyloid precursor protein (APP) gene lies on chromosome 21 and its presence in three copies in DS is thought to largely drive the early onset $A D$. In contrast, intracerebral haemorrhage $(\mathrm{ICH})$, the main clinical consequence of vascular amyloidosis, is a more poorly defined feature of DS. We review recent epidemiological data on stroke (including haemorrhagic stroke) in order to make comparisons with a rare form of familial AD due to duplication (i.e. having three copies) of the APP region on chromosome 21, here called 'dup-APP', which is associated with more frequent and severe $\mathrm{ICH}$. We conclude that although people with DS are at increased risk of ICH, this is less common than in dup-APP, suggesting the presence of mechanisms that act protectively. We review these mechanisms and consider comparative research into DS and dup-APP that may yield further pathophysiological insight.
\end{abstract}


Corresponding author: André Strydom (a.strydom@ucl.ac.uk)

Competing interests: André Strydom has acted as an investigator in clinical trials of medications for Down syndrome sponsored by Roche Pharmaceuticals.

Grant information: This work was funded by Wellcome Trust Strategic Grant No. 098330/Z/12/Z conferred upon The LonDownS Consortium UK. Dean Nizetic is funded also by the Lee Kong Chian School of Medicine, Nanyang Technological University-Singapore Start-up Grant.

Copyright: $(2016$ Buss $L$ et al. This is an open access article distributed under the terms of the Creative Commons Attribution License, which permits unrestricted use, distribution, and reproduction in any medium, provided the original work is properly cited.

How to cite this article: Buss L, Fisher E, Hardy J et al. Intracerebral haemorrhage in Down syndrome: protected or predisposed? [version 1; peer review: 2 approved] F1000Research 2016, 5(F1000 Faculty Rev):876 https://doi.org/10.12688/f1000research.7819.1

First published: 12 May 2016, 5(F1000 Faculty Rev):876 https://doi.org/10.12688/f1000research.7819.1 


\section{Introduction}

Down syndrome (DS), which is due to an extra copy of chromosome 21, is strongly associated with early onset Alzheimer's disease $(\mathrm{AD})^{1}$. This is likely due to the presence of three copies of the gene coding for the amyloid precursor protein $(A P P)$ situated on chromosome 21, resulting in typical pathological features of $\mathrm{AD}$, including senile plaques, composed of small, insoluble fragments of APP referred to as amyloid $\beta$ (A $\beta)$, formed after cleavage by specific secretase enzymes. The ensuing neurocognitive decline is a striking clinical feature of DS.

Cerebral amyloid angiopathy (CAA) results from the deposition of amyloid within the walls of leptomeningeal and cerebral blood vessels ${ }^{2}$ and is present in more than $80 \%$ of $\mathrm{AD}$ brains at post mortem $^{3}$. As in AD, this amyloid derives from APP and is also composed of $A \beta$ fragments. The process of vascular amyloid deposition is largely silent; however, when severe, it may set off a cascade of events resulting in intracerebral haemorrhage (ICH), the main clinical consequence of CAA. CAA-related haemorrhages tend to affect the elderly and occur multiply and in cortical and subcortical (lobar) regions ${ }^{4}$. Like $\mathrm{AD}, \mathrm{CAA}$ occurs frequently in $\mathrm{DS}^{5}$; however, unlike AD dementia, CAA-ICH is not a well-established clinical phenomenon in people with DS.

If CAA-ICH is over-represented in people with DS compared with the euploid population, it is important as an avenue for research and also to clinicians to provide more appropriate care to this group. In this review, we consider the rates of CAA and ICH in individuals with DS and compare these with sporadic $\mathrm{AD}$ as well as a specific form of familial AD due to duplication of the APP region on chromosome 21. Finally, we consider potential mechanisms for apparent differences between these groups.

\section{Intracerebral haemorrhage in Down syndrome: epidemiology}

Until recently, data on CAA-ICH in DS have been limited. There are seven case reports of people with DS suffering severe $\mathrm{ICH}^{6-11}$. Their paucity and noteworthiness suggest that ICH is not part of the experience of clinicians caring for people with DS. However, several mortality studies have reported increased incidence of cerebrovascular events in people with $\mathrm{DS}^{12,13}$ but failed to distinguish between ischaemic and haemorrhagic stroke types.

More recently, Sobey et al. reported population-level data on cardiovascular events in 4081 people with DS and 16,324 agematched controls ${ }^{14}$. Both ischaemic (risk ratio $[\mathrm{RR}]=3.76,95 \%$ confidence interval $[\mathrm{CI}] 2.39,5.92)$ and haemorrhagic $(\mathrm{RR}=3.31$, $95 \%$ CI 1.95, 5.60) strokes are reported as more common amongst people with DS than non-DS controls. The incidence rates for 'any stroke' were $1.3 \%$ in males and $2.3 \%$ in women aged 19 to 50 . For those over 51 years, the corresponding values were $11.3 \%$ in males and $8.2 \%$ in women. For haemorrhagic stroke, the values were $3.8 \%$ in males and $3.3 \%$ in women older than 51 . However, when corrected for existing cardiovascular risk factors (including hypertension, diabetes, smoking, cardiac arrhythmia, sleep apnoea, congenital heart disease, pulmonary hypertension, and Moyamoya disease), the increased risk is largely attenuated for ischaemic but not for haemorrhagic stroke. The authors propose that this excess risk may be accounted for by factors not adjusted for in the regression analysis, such as misclassification of ischaemic-haemorrhagic transformation or anticoagulation, but it is also possible that some of this increased risk for haemorrhagic stroke may be explained by the deposition of vascular amyloid seen in DS, supporting the view that CAA-ICH is relatively common in DS.

\section{Amyloid precursor protein duplication}

The genetic abnormality in DS thought to underpin $\mathrm{AD}$ and CAA is the triplication of the APP gene, along with the rest of chromosome 21. It is proposed that this increased 'dose' of APP provides extra substrate for $\mathrm{A} \beta$ production, which then is deposited as senile plaques in $\mathrm{AD}$ or vascular amyloid in CAA.

APP is cleaved to A $\beta$ fragments by $\gamma$-secretase enzymes whose catalytic subunit is coded for by PSEN1 and PSEN2 genes. There are many well-documented familial forms of AD caused by missense mutations in PSEN1, PSEN2, and the APP gene ${ }^{15}$ that modulate APP processing and increase A $\beta$ deposition. Similarly, hereditary forms of CAA, such as the Dutch type CAA, result from missense mutations in the same three genes ${ }^{16}$.

In addition, a novel genetic form of $\mathrm{AD}$ has been recognised in the last 10 years arising from small internal chromosome 21 duplications ${ }^{17-25}$. These rare copy number variants all result in three copies of $A P P$, collectively known as duplication of $A P P$ (dup- $A P P)^{26}$, and lead to an APP overdose. In this sense, dup-APP differs from other forms of familial $A D$ that are the result of point mutations in APP, PSEN1, or PSEN2. Meaningful comparison can be made with DS, as an additional copy of $A P P$ is present in both diseases; DS differs from dup-APP only in the number of other genes on chromosome 21 that are also trisomic.

The phenotype of dup-APP is one of a highly penetrant AD dementia (frequently associated with seizures ${ }^{17,18,22}$ ) with an onset age of between 39 and 64 years $^{26}$. Significantly, carriers of dup-APP suffer a strikingly high rate of ICH. We estimate that this occurs in approximately a third of the published cases (Table 1 and Figure 1). These haemorrhages are typical of CAA-ICH: multiple and in a lobar distribution. They represent a serious clinical event and are a frequent cause of death in those affected.

Comparison of DS and dup-APP groups shows that the additional copy of the APP gene is sufficient to produce both early onset AD and CAA-ICH. However, although haemorrhagic stroke appears to occur in a significant proportion of elderly people with DS $(3.3 \% \text { to } 3.8 \%)^{14}$, people with dup-APP are much more profoundly affected; the occurrence rate is approximately $30 \%$ (i.e. nearly 10 times higher than in DS). This suggests that triplication of the rest of chromosome 21 may provide partial protection against the pro-haemorrhagic effects of $A P P$ duplication.

\section{Pathophysiological insights}

$\mathrm{A} \beta$ is primarily deposited in the adventitia and media of involved arterioles, and severity of CAA is classified according to spread through the vessel wall: mild CAA is defined as $A \beta$ in the adventitia and some deposits between smooth muscle cells in the media, which are restricted to the tunica media without death of smooth 
Table 1. Summary of intracerebral haemorrhage and dup-APP status in the known kindreds.

\begin{tabular}{|c|c|c|}
\hline Country (reference) & Summation of ICH and dup-APP status & $\begin{array}{l}\text { ICH percentage } \\
\text { (cases/number) }\end{array}$ \\
\hline France (Rovelet-Lecrux et al. $\left.{ }^{17}, 2006\right)$ & $\begin{array}{l}\text { Five kindreds } \\
14 \text { cases confirmed dup-APP } \\
\text { Four cases of ICH in confirmed dup-APP cases } \\
\text { ICH in family } 229 \text { likely represents a dup-APP } \\
\text { case, but genotyping was not done } \\
\text { Two unspecified strokes in non-genotyped } \\
\text { individuals }\end{array}$ & $28 \%(4 / 14)$ \\
\hline France (Wallon et al. $\left.{ }^{24}, 2012\right)$ & $\begin{array}{l}\text { Seven kindreds } \\
19 \text { affected individuals } \\
\text { Cases of ICH in six out of seven kindreds } \\
\text { (unspecified total number) }\end{array}$ & $32 \%(6 / 19)$ \\
\hline The Netherlands (Sleegers et al. ${ }^{18}, 2006$ ) & $\begin{array}{l}\text { One kindred } \\
\text { Four cases confirmed dup-APP } \\
\text { No confirmed cases of ICH }\end{array}$ & $0 \%(0 / 4)$ \\
\hline $\begin{array}{l}\text { Finland (Remes et al. }{ }^{76}, 2004 \text {; Rovelet- } \\
\text { Lecrux et al...20, 2007) }\end{array}$ & $\begin{array}{l}\text { One kindred } \\
14 \text { affected cases (nine confirmed dup-APP) } \\
\text { Five cases of ICH }\end{array}$ & $36 \%(5 / 14)$ \\
\hline UK (McNaughton et al.22, 2012) & $\begin{array}{l}\text { Five probands (confirmed dup-APP) } \\
\text { One ICH }\end{array}$ & $20 \%(1 / 5)$ \\
\hline Japan (Kasuga et al. ${ }^{21}$, 2009) & $\begin{array}{l}\text { Two probands } \\
\text { One case of ICH (on computed tomography } \\
\text { scan of head) }\end{array}$ & $50 \%(1 / 2)$ \\
\hline Sweden (Thonberg et al.25, 2011) & $\begin{array}{l}\text { One proband } \\
\text { No ICH }\end{array}$ & $0 \%(0 / 1)$ \\
\hline \multirow[t]{2}{*}{ Spain (Lladó et al. ${ }^{23}, 2014$ ) } & $\begin{array}{l}\text { One proband } \\
\text { Presented with } \mathrm{ICH}\end{array}$ & $100 \%(1 / 1)$ \\
\hline & & $\begin{array}{l}\text { Total: } 30 \% \\
(18 / 61)\end{array}$ \\
\hline
\end{tabular}

The third column gives the most conservative estimate of the proportion of cases, known to harbour duplication (i.e. having three copies) of the amyloid precursor protein region on chromosome 21 (dup-APP), that are also affected by intracerebral haemorrhage $(\mathrm{ICH})$.

muscle cells. Moderate CAA involves replacement of smooth muscle cells by $A \beta$ and thickening of the media without disruption of the blood-brain barrier (BBB). Severe CAA is defined as extensive $A \beta$ deposition with fragmentation or double-barrelling of the vessel wall, fibrinoid necrosis, and formation of aneurysms ${ }^{27}$.

The order in which vessels are affected typically follows a particular sequence; the leptomeningeal arteries are the first to show signs of pathology, followed by penetrating arterioles in the neocortical grey matter. Furthermore, vessels in the posterior regions of the brain (such as the occipital lobe) are especially affected, although the frontal cortex has also been named as a relatively early site, followed by vessels of the olfactory cortex, hippocampus, and cerebellum, while deep grey and white matter are usually spared ${ }^{3,28,29}$.

ICH due to CAA is typically lobar, and recurrent or multiple, and may occur in the absence of other risk factors for haemorrhage, such as hypertension. Once haemorrhage has occurred, the result is extensive neuronal death as well as a local immune response from microglia, astrocytes, and other immune cells. The salience of ICH in the phenotype of dup-APP is mirrored by the severity of underlying CAA reported in neuropathology studies. In all 13 cases of dup-APP in which neuropathology has been studied (age range of 48 to 58 years), the histological grade of CAA was moderate to severe and CAA was found in every brain reported ${ }^{17,18,20,23}$. By contrast, CAA is not a universal finding in people with DS (Figure 2, data taken from 5). Although most post mortem examinations on people with DS over the age of 50 show CAA from a moderate to severe degree ${ }^{5,30-32}$, a significant proportion (approximately one in five) (Figure 1) remains completely unaffected by CAA.

These observations suggest a complex relationship between increased APP gene dosage and CAA-ICH; individuals with DS show an increased prevalence of CAA-ICH compared with the euploid population but lower prevalence compared with dup-APP individuals. This suggests some degree of protection, but the mechanisms mediating this relationship are as yet unknown. We will consider the possibilities in the following sections. 

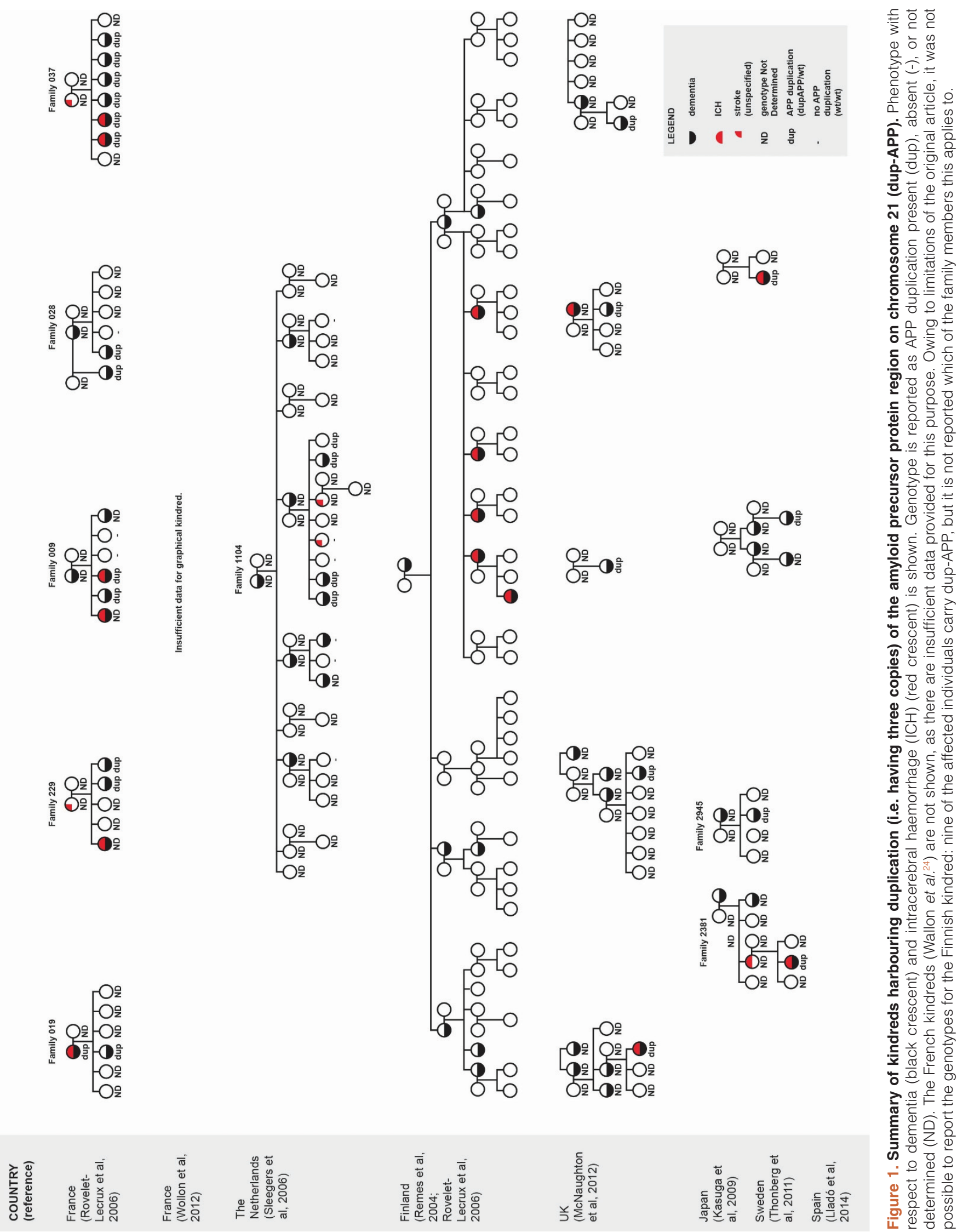

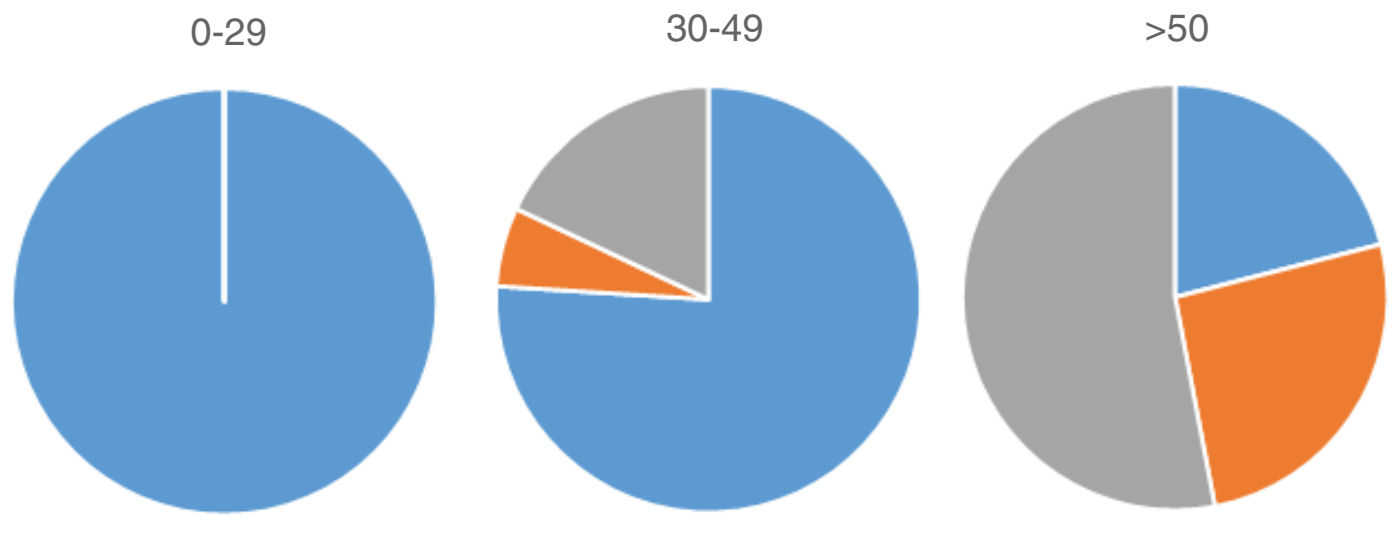

- Abscent = Mild/moderate " Severe

Degree of histological severity of CAA in DS in different age groups

Figure 2. Histological severity of cerebral amyloid angiopathy (system of Vonsattel et al. ${ }^{27}$ ) seen in post mortem studies of people with Down syndrome in different age groups. Age ranges are indicated above charts. Data are reproduced from 5.

\section{$A \beta 40$ versus $A \beta 42$}

The 40-amino-acid peptide $\mathrm{A} \beta(\mathrm{A} \beta$ 40) is more soluble than the longer $A \beta 42$ peptide. $A \beta 40$ tends to be the major form of $A \beta$ in the artery walls in CAA, whereas $\mathrm{A} \beta 42$ is more prominent in plaques. The ratio of $A \beta 40 / 42$ seems to determine to some extent whether $A \beta$ is deposited in brain parenchyma or in the vessel walls. In mutations where $A \beta 42$ is the prominent form of $A \beta$, such as the Indiana and London APP mutations, vascular amyloid seems to be a less prominent feature than parenchymal plaques $^{33}$. In contrast, a high A $\beta$ 40/42 ratio may promote $\mathrm{CAA}^{3}$, as seen in CAA Dutch type ${ }^{34}$.

Cellular studies using cortical neurones generated from induced pluripotent stem cells harbouring APP duplication or DS (trisomy of chromosome 21) have addressed the issue of $A \beta 40 / 42$ ratio. Both dup-APP ${ }^{35,36}$ and trisomy $21^{37,38}$ cells overproduce $\mathrm{A} \beta$ peptide compared with control cells, although the relative overproduction has not been compared in the same study protocol. Surprisingly, in dup-APP cells, the A $\beta$ 40/A $\beta 42$ ratio is unchanged compared with control cells, which is also the case in mouse studies of overexpression of wild-type $A P P$, resulting in an increase of both $A \beta 40$ and $\mathrm{A} \beta 42$ with the ratio preserved ${ }^{34}$. In contrast, trisomic cells exhibit an increased $A \beta$ 40/A $\beta 42$ ratio compared with dup-APP and control cells ${ }^{35}$.

In post mortem studies, the composition of vascular and parenchymal amyloid appears very similar in dup-APP and DS brains when stained with antibodies specific to either $A \beta 40$ or $A \beta 42$. Older individuals with $\mathrm{DS}^{30,31}$ and dup-APP cases ${ }^{17,19}$ have extensive $A \beta 40$ deposition in vascular walls, preceded temporarily by low-level $\mathrm{A} \beta 42$ deposition in $\mathrm{DS}^{31}$. Parenchymal plaques are present in both groups to a similar extent and stain mostly prominently for $\mathrm{A} \beta 42$.

Given the cellular data, it seems that the $A \beta$ 40/42 ratio may be elevated in DS compared with dup-APP and controls; however, this is not reflected strongly in histopathology studies, which do not suggest significant differences in neuropathology between DS and dup-APP. An increased A $\beta$ 40/42 ratio in DS would predict more severe CAA and predisposition to $\mathrm{ICH}$; however, it does not explain the relative protection compared with dup-APP. Other mechanisms may be at play.

\section{A $\beta$ clearance in Down syndrome}

Increased amyloid in the brain can be the result of either increased production or reduced clearance. As discussed in the preceding section, there is increased production of amyloid in both dup-APP and DS because of the presence of an extra copy of the APP gene in both cases. The $A \beta 40 / A \beta 42$ ratios do not explain the apparent difference between dup-APP and DS in severity of CAA and prevalence of ICH. It is possible that a difference in clearance of vascular amyloid is the key factor.

$A \beta$ is cleared from the brain by several pathways: (1) endocytosis by astrocytes and microglial cells ${ }^{39}$, (2) enzymatic degradation ${ }^{40}$, or (3) removal through the $\mathrm{BBB}^{41}$ or along peri-arterial spaces ${ }^{42}$.

Microglia are the brain's tissue macrophages; they have been shown to clear $\mathrm{A} \beta$ by endocytosis and internal degradation ${ }^{39}$. However, their exact role in this process is still poorly understood. Recent post mortem studies of brains from individuals with DS who were not older than 40 (i.e. before onset of AD) showed a heightened neuroinflammatory response, which was further increased in older individuals with DS and AD. Microglial cell activation increases with age in $\mathrm{DS}^{43}$ but may be lower compared with sporadic $\mathrm{AD}$ cases, despite higher levels of A $\beta$ accumulation, and DS brains were characterised by a unique inflammatory phenotype associated with the formation of immune complexes (M2b) ${ }^{44}$. The authors hypothesised that accumulation of CAA may result in vascular leakage, with extravasation of $\operatorname{IgG}$ into the brain, which in turn may promote the M2b phenotype. Intriguingly, previous work by 
this group showed that an M2b inflammatory phenotype induced by IgG infusions into brains of an amyloid mouse model promoted clearance of amyloid deposits, suggesting a protective mechanism ${ }^{45}$. However, if specific changes in neuroinflammation and microglial cells exist in DS, they have not yet been fully investigated and neither has the nature of these mechanisms been explored in dup-APP. Furthermore, since the bulk of extracellular A $\beta$ clearance is via the BBB or interstitial fluid flow ${ }^{46}$, it seems unlikely to be the main factor accounting for the relative protection against CAA-ICH in DS as compared with dup-APP.

Clearance of $A \beta$ locally is also performed by the cerebrovascular smooth muscle cells and astrocytes through the low-density lipoprotein receptor-related protein-1 (LRP1)-mediated endocytic pathway $^{47}$. The levels of LRP1 are reduced in patients with AD, and LRP1 levels also decline with age ${ }^{48}$. Recently, assays were developed to model these processes by using induced pluripotent stem cell models ${ }^{49}$. The effects of dup-APP and trisomy 21 on these processes are yet to be studied.

Physiological degradation of $\mathrm{A} \beta$ involves metallopeptidases such as neprilysin $(\mathrm{NEP})^{46}$. NEP degradation of $\mathrm{A} \beta$ seems to be protective against $\mathrm{CAA}^{50}$. NEP expression in vascular smooth muscle cells is inversely correlated with degree of vascular $A \beta^{51,52}$, and a polymorphism in the NEP promotor region that may reduce NEP transcription levels is associated with more severe $\mathrm{CAA}^{53}$. There is little published research on enzymatic degradation of $A \beta$ in DS. However, one study by Miners et al. (2010) showed NEP levels to be increased in DS brains (age range of 10 to 80 years) compared with non-DS controls, and NEP level was strongly correlated with insoluble $A \beta$ concentration ${ }^{54}$. This contrasts with evidence from sporadic AD showing decreased NEP immunoreactivity compared with age-matched controls ${ }^{55}$. It is possible that in DS there is greater capacity for NEP expression conferring some protective effect against CAA.

Transport of $\mathrm{A} \beta$ across the $\mathrm{BBB}$ is receptor mediated. The lowdensity lipoprotein pathway transports $A \beta$ from the brain interstitial and cerebrospinal fluid compartments into the circulation ${ }^{56}$. To the best of our knowledge, specific abnormalities of the BBB have not been demonstrated in DS; however, lipid processing is known to be abnormal ${ }^{57}$, indirectly supporting the idea that BBB-mediated efflux of $A \beta$ from the brain could be altered in this group.

A proportion of neuronally produced $\mathrm{A} \beta$ flows with the interstitial fluid along perivascular spaces to be excreted into the cerebrospinal fluid and drained into the systemic circulation ${ }^{42}$. Although the contribution of perivascular drainage to CAA is by no means clear, it has been proposed to be a compensatory mechanism when other routes fail, and this may underlie the strong association between age and the development of CAA and AD pathology in the general population. Perivascular drainage is proposed to rely on countercurrent flow of lymphatics driven by the arterial pulsation ${ }^{58}$. As the arteries are increasingly affected by atherosclerosis or inflammation during ageing, they become more rigid with less effective contractile function and perivascular drainage. As individuals with DS appear to be somewhat protected against atherosclerosis ${ }^{57}$, this could be another protective mechanism, resulting in better $A \beta$ drainage and less severe CAA.

\section{Other potentially protective mechanisms}

DS may be associated with several other protective mechanisms. It is possible that DS differs from dup-APP in the response to A $\beta$-related cell damage. Evidence from mouse model studies shows that immunotherapy against amyloid increases CAA and may also result in increased micro-haemorrhages ${ }^{59}$, suggesting an important role for the immune system in the pathophysiology of CAA. The innate immune system may differ in DS, thus affecting response to $\mathrm{AB}$ deposition. This possibility remains to be explored. Furthermore, the effect of free radicals may contribute to vascular damage, and although oxidative stress is a prominent feature of DS, it has been shown that increased activity of some anti-oxidant enzymes such as superoxide dismutase (SOD1, encoded on chromosome 21 and triplicated in DS) is associated with less cognitive decline, suggesting another potential protective mechanism ${ }^{60,61}$. In contrast, experiments using the $\mathrm{Tg} 2576$ mouse model have resulted in the suggestion that $\mathrm{A} \beta$-induced oxidative stress causes DNA damage and excess opening of TRPM2 calcium channels, leading to calcium overload, which in turn results in endothelial dysfunction ${ }^{62}$.

Specific apolipoprotein $\mathrm{E}(A P O E)$ genotypes ( $\varepsilon 4$ and $\varepsilon 2)$ are known risk factors for more severe CAA and $\mathrm{ICH}$ in the general population $^{63-65}$. Two of the seven cases of ICH in DS report APOE genotype, both carrying high-risk variants $\left(\varepsilon 2 / \varepsilon 4^{7}\right.$ and $\left.\varepsilon 4 / \varepsilon 4^{9}\right)$. This contrasts with dup-APP, where all 11 cases of ICH in which APOE genotype is reported carry a low-risk variant $(\varepsilon 3 / \varepsilon 3 \mathrm{n}=9, \varepsilon 3 / \varepsilon 4$ $\mathrm{n}=2$ ). These very limited data suggest an importance of $A P O E$ genotype as a risk factor for CAA-ICH in DS and possible APOE independence of ICH in dup-APP; further investigation is needed. However, it is noteworthy that $A P O E$ is mapped to chromosome 19 , not chromosome 21 , and this by itself is unlikely to explain differences between DS and dup-APP groups. In this regard, the ATP binding-cassette G1 ( $A B C G 1)$ gene may be a more relevant candidate, as it is located on chromosome 21 and is thought to be responsible for cholesterol efflux onto apolipoproteins ${ }^{66}$. However, cellular studies provide conflicting evidence suggesting that $A B C G 1$ overexpression may increase ${ }^{67}$ or reduce ${ }^{68} \mathrm{~A} \beta$ production. Evidence from mouse models is also conflicting. One study examined transgenic mice with a sixfold overexpression of $A B C G 1$ that did not exhibit increased levels of $\mathrm{A} \beta^{69}$; by contrast, $A P O E \varepsilon 4$ mice treated with bexarotene, an agent that indirectly upregulates $A B C G 1$ and $A B C A 1$, reversed hippocampal $A \beta 42$ deposition $^{70}$. The evidence is unclear and its relation to $\mathrm{CAA}$ and $\mathrm{ICH}$ even more so.

Finally, individuals with DS of all ages are less at risk from hypertension than their peers in the general population (incidence rate ratio $0.3,95 \% \mathrm{CI} 0.3$ to 0.4$)^{71}$. Although hypertension has not (yet) been clearly related to CAA-ICH in DS and in fact gives rise to a different pattern of haemorrhage, it is theoretically possible that higher blood pressure may increase the likelihood of aneurism and bleeds in vessels severely affected by CAA in those with dup-APP compared with individuals with DS.

\section{Further research}

Further epidemiological data are needed in DS regarding haemorrhagic stroke - a diagnostic category, not a single entity. CAA-ICH can be distinguished from other forms of haemorrhagic stroke on clinical grounds by using the validated Boston criteria ${ }^{4}$. 
The age-related risk for CAA-ICH in DS should be explored using susceptibility weighted imaging magnetic resonance imaging scans to detect microbleeds, which will allow comparison against dup-APP and sporadic AD to confirm relative burden of disease in these groups.

The role of factors involved in the clearance of A $\beta$ in DS should be explored in more depth, as this could help to reveal potential drug targets to reduce CAA and associated ICH. Specifically, we have identified gaps in knowledge of the relationship between $\mathrm{A} \beta$ 40/A $\beta 42$ ratios and development of CAA and $\mathrm{ICH}$ in DS, on one hand, and $A \beta$ clearance by endocytosis, enzymatic degradation, and removal through the $\mathrm{BBB}$, on the other. Furthermore, direct comparison between DS and dup-APP cases and models is required. In this regard, mouse modelling with partial triplication of areas of chromosome 21 might identify an area of the chromosome that modulates the risk of CAA-ICH. CAA develops in several AD mouse models, including the Tg2576 (APP expressed under the PrP promoter) ${ }^{72}$, and $\mathrm{J} 20$ mouse model ( $A P P$ transgenics with Swedish and Indiana mutations), particularly after 11 to 12 months of age $\mathrm{e}^{73,74}$. The Tg-SwDI mouse is the most widely used model for studying CAA, containing the Swedish, Dutch, and Iowa mutations and developing CAA at 6 months ${ }^{75}$. Therefore, different partial trisomy strains could be crossed to transgenic mice expressing forms of APP that give rise to CAA and micro-haemorrhages; double mutant progeny could be assessed for CAA to see whether regions of chromosome 21 mediate increased or reduced pathology compared with mice carrying the APP transgene alone. If such a region were found, then it would give us dosage-sensitive candidate genes affecting the risk of CAA-ICH. Table 2 summarises some of the important unanswered questions generated by this review.

\section{Conclusions}

There is much variation between individuals with DS and development of clinical dementia and associated CAA and ICH. Variability in phenotypic and pathological expression, however, is not unique to $\mathrm{DS}$ but has also been reported in familial AD, suggesting the presence of genetic and non-genetic factors with diseasemodifying effects. Intriguingly, individuals with DS appear to have much lower risk for developing ICH as well as some indications of less severe CAA when compared with families with dup-APP, despite also having three copies of the APP gene, suggesting that other genes on chromosome 21 may provide some protection

\section{Table 2. Summary of further research questions resulting from this review and corresponding suggestions for further enquiry.}

\begin{tabular}{|c|c|}
\hline Further research questions & Possible investigative strategy \\
\hline $\begin{array}{l}\text { What is the true age-related prevalence } \\
\text { of } \mathrm{CAA}-\mathrm{ICH} \text { in individuals with DS? }\end{array}$ & $\begin{array}{l}\text { 1. Further epidemiological studies comparing DS against general AD population } \\
\text { and dup-APP are required } \\
\text { 2. Susceptibility weighted imaging magnetic resonance imaging studies to detect } \\
\text { microbleeds in DS population }\end{array}$ \\
\hline $\begin{array}{l}\text { Is there a region of chromosome } 21 \text { that } \\
\text { specifically modifies the risk of CAA? }\end{array}$ & $\begin{array}{l}\text { Different partial trisomy mouse strains could be crossed with transgenic mice } \\
\text { expressing forms of APP that give rise to CAA; double mutant progeny could be } \\
\text { assessed for CAA and micro-haemorrhage }\end{array}$ \\
\hline $\begin{array}{l}\text { Does clearance of } A \beta \text { in DS differ from } \\
\text { dup-APP? }\end{array}$ & $\begin{array}{l}\text { 1. Establish the relationship between } A \beta 40 / A \beta 42 \text { ratios and development of CAA } \\
\text { and ICH in DS by using neuropathological studies } \\
\text { 2. Experimental studies of } A \beta \text { clearance by endocytosis, enzymatic degradation, } \\
\text { and removal through the blood-brain barrier by using animal and cellular models } \\
\text { 3. Compare DS and dup-APP by using neuropathological and cellular studies and } \\
\text { animal models }\end{array}$ \\
\hline $\begin{array}{l}\text { What is the role of APOE genotype in } \\
\text { CAA-ICH in the DS population and in } \\
\text { dup-APP? }\end{array}$ & $\begin{array}{l}\text { Population-based cohort study in DS individuals stratified by APOE genotype with } \\
\text { imaging-confirmed micro-haemorrhage or ICH as the main outcome measure; } \\
\text { collect similar data in families with dup-APP }\end{array}$ \\
\hline $\begin{array}{l}\text { To what extent do other factors } \\
\text { influence CAA development in DS? }\end{array}$ & $\begin{array}{l}\text { 1. Explore the relationship between the immune system and CAA-ICH by using } \\
\text { genomic, neuropathological, and immunological studies } \\
\text { 2. Explore the role of oxidative stress, and in particular antioxidant enzymes such } \\
\text { as SOD, in CAA-ICH using mouse model experiments and longitudinal human } \\
\text { biomarker studies } \\
\text { 3. Explore the role of vascular risk factors such as blood pressure in ICH in DS by } \\
\text { using population-based epidemiological studies }\end{array}$ \\
\hline
\end{tabular}

$A \beta$, amyloid-beta; AD, Alzheimer's disease; APOE, apolipoprotein E; APP, amyloid precursor protein; CAA, cerebral amyloid angiopathy; DS, Down syndrome; dup-APP, duplication (i.e. having three copies) of the amyloid precursor protein region on chromosome 21 ; ICH, intracerebral haemorrhage; SOD, superoxide dismutase. 
against the effects of $A P P$ overdose. This review of the literature suggests that this lower prevalence and seemingly protective effect of trisomy 21 may be related to a difference in the clearance of $\mathrm{A} \beta$, although other factors such as neuroinflammation, atherosclerosis, oxidative stress, and lower blood pressure could also have a role. Insights into these factors may provide important information about mechanisms of disease, which can be exploited to identify treatment strategies. For example, if it turns out that low blood pressure helps to protect individuals with DS from ICH, then that would suggest an important strategy to offer individuals from families with familial $\mathrm{AD}$ mutations at risk for $\mathrm{CAA}$ and $\mathrm{ICH}$.

\section{Competing interests}

André Strydom has acted as an investigator in clinical trials of medications for Down syndrome sponsored by Roche Pharmaceuticals.

\section{Grant information}

This work was funded by Wellcome Trust Strategic Grant No. 098330/Z/12/Z conferred upon The LonDownS Consortium UK. Dean Nizetic is funded also by the Lee Kong Chian School of Medicine, Nanyang Technological University-Singapore Start-up Grant.
1. Holland AJ, Hon J, Huppert FA, et al.: Incidence and course of dementia in people with Down's syndrome: findings from a population-based study. $J$ Intellect Disabil Res. 2000; 44(Pt 2): 138-46.

PubMed Abstract | Publisher Full Text

2. Vinters HV, Gilbert JJ: Cerebral amyloid angiopathy: incidence and complications in the aging brain. II. The distribution of amyloid vascular changes. Stroke. 1983; 14(6): 924-8. PubMed Abstract | Publisher Full Text

3. Pezzini A, Del Zotto E, Volonghi I, et al:: Cerebral amyloid angiopathy: a common cause of cerebral hemorrhage. Curr Med Chem. 2009; 16(20): 2498-513. PubMed Abstract | Publisher Full Text

4. Knudsen KA, Rosand J, Karluk D, et al.: Clinical diagnosis of cerebral amyloid angiopathy: validation of the Boston criteria. Neurology. 2001; 56(4): 537-9. PubMed Abstract | Publisher Full Text

5. Mann DM: Cerebral amyloidosis, ageing and Alzheimer's disease; a contribution from studies on Down's syndrome. Neurobiol Aging. 1989; 10(5): 397-9; discussion 412-4.

PubMed Abstract | Publisher Full Text

6. Belza MG, Urich H: Cerebral amyloid angiopathy in Down's syndrome. Clin Neuropathol. 1986; 5(6): 257-60

PubMed Abstract

7. McCarron MO, Nicoll JA, Graham DI: A quartet of Down's syndrome, Alzheimer's disease, cerebral amyloid angiopathy, and cerebral haemorrhage: interacting genetic risk factors. J Neurol Neurosurg Psychiatr. 1998; 65(3): 405-6. PubMed Abstract | Publisher Full Text | Free Full Text

8. Donahue JE, Khurana JS, Adelman LS: Intracerebral hemorrhage in two patients with Down's syndrome and cerebral amyloid angiopathy. Acta Neuropathol. 1998; 95(2): 213-6.

PubMed Abstract | Publisher Full Text

9. $\quad F$ Naito K, Sekijima Y, Ikeda S: Cerebral amyloid angiopathy-related hemorrhage in a middle-aged patient with Down's syndrome. Amyloid. 2008; 15(4): 275-7.

PubMed Abstract | Publisher Full Text | F1000 Recommendation

10. F Mendel T, Bertrand E, Szpak GM, et al:: Cerebral amyloid angiopathy as a cause of an extensive brain hemorrhage in adult patient with Down's syndrome - a case report. Folia Neuropathol. 2010; 48(3): 206-11. PubMed Abstract | F1000 Recommendation

11. F Jastrzębski K, Kacperska MJ, Majos A, et al:: Hemorrhagic stroke, cerebral amyloid angiopathy, Down syndrome and the Boston criteria. Neurol Neurochir Pol. 2015; 49(3): 193-6.

PubMed Abstract | Publisher Full Text | F1000 Recommendation

12. Scholl $\mathrm{T}$, Stein $\mathrm{Z}$, Hansen $\mathrm{H}$ : Leukemia and other cancers, anomalies and infections as causes of death in Down's syndrome in the United States during 1976. Dev Med Child Neurol. 1982; 24(6): 817-29. PubMed Abstract | Publisher Full Text

13. Day SM, Strauss DJ, Shavelle RM, et al.: Mortality and causes of death in persons with Down syndrome in California. Dev Med Child Neurol. 2005; 47(3) $171-6$.

PubMed Abstract | Publisher Full Text

14. F Sobey CG, Judkins CP, Sundararajan V, et al:: Risk of Major Cardiovascula Events in People with Down Syndrome. PLoS One. 2015; 10(9): e0137093. PubMed Abstract | Publisher Full Text | Free Full Text | F1000 Recommendation

15. Bekris LM, Yu CE, Bird TD, et al:: Genetics of Alzheimer disease. J Geriatr
Psychiatry Neurol. 2010; 23(4): 213-27.

PubMed Abstract | Publisher Full Text | Free Full Text

16. Levy E, Carman MD, Fernandez-Madrid IJ, et al.: Mutation of the Alzheimer's disease amyloid gene in hereditary cerebral hemorrhage, Dutch type. Science. 1990; 248(4959): 1124-6.

PubMed Abstract | Publisher Full Text

17. F Rovelet-Lecrux A, Hannequin D, Raux G, et al: APP locus duplication causes autosomal dominant early-onset Alzheimer disease with cerebral amyloid angiopathy. Nat Genet. 2006; 38(1): 24-6.

PubMed Abstract | Publisher Full Text | F1000 Recommendation

18. F Sleegers $\mathrm{K}$, Brouwers N, Gijselinck I, et al:: APP duplication is sufficient to cause early onset Alzheimer's dementia with cerebral amyloid angiopathy. Brain. 2006; 129(Pt 11): 2977-83.

PubMed Abstract | Publisher Full Text | F1000 Recommendation

19. F Cabrejo L, Guyant-Maréchal L, Laquerrière A, et al:: Phenotype associated with APP duplication in five families. Brain. 2006; 129(Pt 11): 2966-76. PubMed Abstract | Publisher Full Text | F1000 Recommendation

20. F Rovelet-Lecrux A, Frebourg T, Tuominen H, et al:: APP locus duplication in a Finnish family with dementia and intracerebral haemorrhage. $J$ Neurol Neurosurg Psychiatr. 2007; 78(10): 1158-9.

PubMed Abstract | Publisher Full Text | Free Full Text | F1000 Recommendation

21. F Kasuga $\mathrm{K}$, Shimohata $\mathrm{T}$, Nishimura A, et al.: Identification of independent APP locus duplication in Japanese patients with early-onset Alzheimer disease. J Neurol Neurosurg Psychiatr. 2009; 80(9): 1050-2. PubMed Abstract | Publisher Full Text | F1000 Recommendation

22. McNaughton D, Knight W, Guerreiro R, et al.: Duplication of amyloid precursor protein (APP), but not prion protein (PRNP) gene is a significant cause of early onset dementia in a large UK series. Neurobiol Aging. 2012; 33(2): 426.e13-21. PubMed Abstract | Publisher Full Text | Free Full Text

23. F Lladó A, Grau-Rivera O, Sánchez-Valle R, et al:: Large APP locus duplication in a sporadic case of cerebral haemorrhage. Neurogenetics. 2014: 15(2): 145-9. PubMed Abstract | Publisher Full Text | F1000 Recommendation

24. F Wallon D, Rousseau S, Rovelet-Lecrux A, et al.: The French series of autosomal dominant early onset Alzheimer's disease cases: mutation spectrum and cerebrospinal fluid biomarkers. J Alzheimers Dis. 2012; 30(4): 847-56.

PubMed Abstract | Publisher Full Text | F1000 Recommendation

25. F Thonberg H, Fallström M, Björkström J, et al:: Mutation screening of patients with Alzheimer disease identifies APP locus duplication in a Swedish patient. BMC Res Notes. 2011; 4: 476.

PubMed Abstract | Publisher Full Text | Free Full Text | F1000 Recommendation

26. Wiseman FK, Al-Janabi T, Hardy J, et al.: A genetic cause of Alzheimer disease: mechanistic insights from Down syndrome. Nat Rev Neurosci. 2015; 16(9): 564-74.

PubMed Abstract | Publisher Full Text | Free Full Text

27. Vonsattel JP, Myers RH, Hedley-Whyte ET, et al:: Cerebral amyloid angiopathy without and with cerebral hemorrhages: a comparative histological study. Ann Neurol. 1991; 30(5): 637-49.

PubMed Abstract | Publisher Full Text

28. Cupino TL, Zabel MK: Alzheimer's silent partner: cerebral amyloid angiopathy. Trans/ Stroke Res. 2014; 5(3): 330-7. PubMed Abstract | Publisher Full Text 
29. Xu D, Yang C, Wang L: Cerebral amyloid angiopathy in aged Chinese: a cliniconeuropathological study. Acta Neuropathol. 2003; 106(1): 89-91. PubMed Abstract

30. Iwatsubo T, Mann DM, Odaka A, et al:: Amyloid beta protein (A beta) deposition: A beta 42(43) precedes A beta 40 in Down syndrome. Ann Neurol. 1995; 37(3): 294-9.

PubMed Abstract | Publisher Full Text

31. Lemere CA, Blusztajn JK, Yamaguchi $\mathrm{H}$, et al:: Sequence of deposition of heterogeneous amyloid beta-peptides and APO E in Down syndrome: implications for initial events in amyloid plaque formation. Neurobiol Dis. 1996; 3(1): 16-32.

PubMed Abstract | Publisher Full Text

32. Motte J, Williams RS: Age-related changes in the density and morphology of plaques and neurofibrillary tangles in Down syndrome brain. Acta Neuropatho. plaques and neuroti

PubMed Abstract | Publisher Full Text

33. De Jonghe C, Esselens C, Kumar-Singh S, et al: Pathogenic APP mutation near the gamma-secretase cleavage site differentially affect Abeta secretion and APP C-terminal fragment stability. Hum Mol Genet. 2001; 10(16): 1665-71. PubMed Abstract | Publisher Full Text

34. F Herzig MC, Winkler DT, Burgermeister P, et al:: Abeta is targeted to the vasculature in a mouse model of hereditary cerebral hemorrhage with vasculature in a mouse model of hereditary cercidosis. Nat Neurosci. 2004; 7(9): 954-60. amyloidosis. Nat Neurosci. 2004; 7(9): 954-60.

PubMed Abstract | Publisher Full Text | F1000 Recommendation

35. Moore S, Evans LD, Andersson T, et al:: APP metabolism regulates tau proteostasis in human cerebral cortex neurons. Cell Rep. 2015; 11(5): 689-96. PubMed Abstract | Publisher Full Text | Free Full Text

36. F Israel MA, Yuan SH, Bardy C, et al:: Probing sporadic and familial Alzheimer's disease using induced pluripotent stem cells. Nature. 2012; 482(7384): 216-20.

PubMed Abstract | Publisher Full Text | Free Full Text | F1000 Recommendation

37. F Shi Y, Kirwan P, Smith J, et al.: A human stem cell model of early Alzheimer's disease pathology in Down syndrome. Sci Transl Med. 2012; 4(124): 124 ra29.

PubMed Abstract | Publisher Full Text | Free Full Text | F1000 Recommendation

38. Murray A, Letourneau A, Canzonetta $\mathrm{C}$, et al.: Brief report: isogenic induced pluripotent stem cell lines from an adult with mosaic down syndrome model accelerated neuronal ageing and neurodegeneration. Stem Cells. 2015; 33(6): 2077-84.

PubMed Abstract | Publisher Full Text | Free Full Text

39. Lee CY, Landreth GE: The role of microglia in amyloid clearance from the $A D$ brain. J Neural Transm (Vienna). 2010; 117(8): 949-60. PubMed Abstract | Publisher Full Text | Free Full Text

40. Selkoe DJ: Clearing the brain's amyloid cobwebs. Neuron. 2001; 32(2): 177-80. PubMed Abstract | Publisher Full Text

41. Shibata M, Yamada S, Kumar SR, et al.: Clearance of Alzheimer's amyloid-ss peptide from brain by LDL receptor-related protein-1 at the blood-brain barrier. $J$ Clin Invest. 2000; 106(12): 1489-99.

PubMed Abstract | Publisher Full Text | Free Full Text

42. Weller RO, Djuanda E, Yow HY, et al:: Lymphatic drainage of the brain and the pathophysiology of neurological disease. Acta Neuropathol. 2009; 117(1): 1-14. PubMed Abstract | Publisher Full Text

43. F Portelius $\mathrm{E}$, Soininen $\mathrm{H}$, Andreasson $\mathrm{U}$, et al:: Exploring Alzheimer molecula pathology in Down's syndrome cerebrospinal fluid. Neurodegener Dis. 2014; 14(2): 98-106.

PubMed Abstract | Publisher Full Text | F1000 Recommendation

44. F Wilcock DM, Hurban J, Helman AM, et al.: Down syndrome individuals with Alzheimer's disease have a distinct neuroinflammatory phenotype compared to sporadic Alzheimer's disease. Neurobiol Aging. 2015; 36(9): 2468-74. PubMed Abstract | Publisher Full Text | Free Full Text | F1000 Recommendation

45. F Sudduth TL, Greenstein A, Wilcock DM: Intracranial injection of Gammagard, a human IVIg, modulates the inflammatory response of the brain and lowers $A \beta$ in APP/PS1 mice along a different time course than anti-A $\beta$ antibodies. J Neurosci. 2013; 33(23): 9684-92.

PubMed Abstract | Publisher Full Text | Free Full Text | F1000 Recommendation

46. Tarasoff-Conway JM, Carare RO, Osorio RS, et al:: Clearance systems in the brain-implications for Alzheimer disease. Nat Rev Neurol. 2015; 11(8): 457-70. PubMed Abstract | Publisher Full Text | Free Full Text

47. F Kanekiyo T, Liu CC, Shinohara M, et al.: LRP1 in brain vascular smooth muscle cells mediates local clearance of Alzheimer's amyloid- $\beta$. J Neurosci. 2012; 32(46): 16458-65.

PubMed Abstract | Publisher Full Text | Free Full Text | F1000 Recommendation

48. Deane R, Zlokovic BV: Role of the blood-brain barrier in the pathogenesis of Alzheimer's disease. Curr Alzheimer Res. 2007; 4(2): 191-7. PubMed Abstract | Publisher Full Text

49. F Cheung C, Goh YT, Zhang J, et al:: Modeling cerebrovascular pathophysiology in amyloid- $\beta$ metabolism using neural-crest-derived smooth muscle cells. Cell Rep. 2014; 9(1): 391-401.

PubMed Abstract | Publisher Full Text | F1000 Recommendation

50. Miners JS, Baig S, Palmer J, et al:: Abeta-degrading enzymes in Alzheimer's disease. Brain Pathol. 2008; 18(2): 240-52.

PubMed Abstract | Publisher Full Text

51. Carpentier M, Robitaille $Y$, DesGroseillers L, et al.: Declining expression of neprilysin in Alzheimer disease vasculature: possible involvement in cerebral amyloid angiopathy. J Neuropathol Exp Neurol. 2002; 61(10): 849-56. PubMed Abstract | Publisher Full Text

52. Miners JS, Van Helmond Z, Chalmers K, et al.: Decreased expression and activity of neprilysin in Alzheimer disease are associated with cerebral amyloid angiopathy. J Neuropathol Exp Neurol. 2006; 65(10): 1012-21. PubMed Abstract | Publisher Full Text

53. Yamada $\mathrm{M}$, Sodeyama $\mathrm{N}$, Itoh $\mathrm{Y}$, et al.: Association of neprilysin polymorphism with cerebral amyloid angiopathy. J Neurol Neurosurg Psychiatr. 2003; 74(6): 749-51.

PubMed Abstract | Publisher Full Text | Free Full Text

54. $\quad F$ Miners JS, Morris S, Love $S$, et al:: Accumulation of insoluble amyloid- $\beta$ in down's syndrome is associated with increased BACE-1 and neprilysin activities. J Alzheimers Dis. 2011; 23(1): 101-8.

PubMed Abstract | Publisher Full Text | F1000 Recommendation

55. Wang DS, Lipton RB, Katz MJ, et al.: Decreased neprilysin immunoreactivity in Alzheimer disease, but not in pathological aging. J Neuropathol Exp Neurol. 2005; 64(5): 378-85

PubMed Abstract | Publisher Full Text

56. Deane R, Wu Z, Zlokovic BV: RAGE (yin) versus LRP (yang) balance regulates alzheimer amyloid beta-peptide clearance through transport across the blood-brain barrier. Stroke. 2004; 35(11 Suppl 1): 2628-31.

PubMed Abstract | Publisher Full Text

57. Lott IT, Head E: Alzheimer disease and Down syndrome: factors in pathogenesis. Neurobiol Aging. 2005; 26(3): 383-9.

PubMed Abstract | Publisher Full Text

58. Schley D, Carare-Nnadi R, Please CP, et al.: Mechanisms to explain the reverse perivascular transport of solutes out of the brain. J Theor Biol. 2006; 238(4): 962-74.

PubMed Abstract | Publisher Full Text

59. Wilcock DM, Colton CA: Immunotherapy, vascular pathology, and microhemorrhages in transgenic mice. CNS Neurol Disord Drug Targets. 2009; 8(1): 50-64.

PubMed Abstract | Publisher Full Text | Free Full Text

60. Zis $\mathrm{P}$, Dickinson $\mathrm{M}$, Shende $\mathrm{S}$, et al.: Oxidative stress and memory decline in adults with Down syndrome: longitudinal study. J Alzheimers Dis. 2012; 31(2): 277-83.

PubMed Abstract | Publisher Full Text

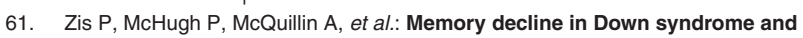
its relationship to iPF2alpha, a urinary marker of oxidative stress. PLOS One. 2014; 9(6): e97709.

PubMed Abstract | Publisher Full Text | Free Full Text

62. F Park L, Wang G, Moore J, et al.: The key role of transient receptor potentia melastatin-2 channels in amyloid- $\beta$-induced neurovascular dysfunction. Nat Commun. 2014; 5: 5318.

PubMed Abstract | Publisher Full Text | Free Full Text | F1000 Recommendation

63. Greenberg SM, Rebeck GW, Vonsattel JP, et al.: Apolipoprotein E epsilon $\mathbf{4}$ and cerebral hemorrhage associated with amyloid angiopathy. Ann Neurol. 1995; 38(2): 254-9.

PubMed Abstract | Publisher Full Text

64. Greenberg SM, Briggs ME, Hyman BT, et al.: Apolipoprotein E epsilon 4 is associated with the presence and earlier onset of hemorrhage in cerebral amyloid angiopathy. Stroke. 1996; 27(8): 1333-7.

PubMed Abstract | Publisher Full Text

65. Nicoll JA, Burnett C, Love S, et al.: High frequency of apolipoprotein E epsilon 2 allele in hemorrhage due to cerebral amyloid angiopathy. Ann Neurol. 1997; 41(6): 716-21.

PubMed Abstract | Publisher Full Text

66. Phillips MC: Molecular mechanisms of cellular cholesterol efflux. J Biol Chem. 2014; 289(35): 24020-9.

PubMed Abstract | Publisher Full Text | Free Full Text

67. Tansley GH, Burgess BL, Bryan MT, et al:: The cholesterol transporter ABCG1 modulates the subcellular distribution and proteolytic processing of betaamyloid precursor protein. J Lipid Res. 2007; 48(5): 1022-34. PubMed Abstract | Publisher Full Text

68. Kim WS, Rahmanto AS, Kamili A, et al:: Role of ABCG1 and ABCA1 in regulation of neuronal cholesterol efflux to apolipoprotein $E$ discs and suppression of amyloid-beta peptide generation. J Biol Chem. 2007; 282(5): 2851-61. PubMed Abstract | Publisher Full Text

69. F Burgess BL, Parkinson PF, Racke MM, et al:: ABCG1 influences the brain cholesterol biosynthetic pathway but does not affect amyloid precursor protein or apolipoprotein E metabolism in vivo. J Lipid Res. 2008; 49(6): 1254-67. PubMed Abstract | Publisher Full Text | F1000 Recommendation

70. F Boehm-Cagan A, Michaelson DM: Reversal of apoE4-driven brain pathology and behavioral deficits by bexarotene. J Neurosci. 2014; 34(21): 7293-301. PubMed Abstract | Publisher Full Text | F1000 Recommendation

71. F Alexander $\mathrm{M}$, Petri $\mathrm{H}$, Ding $\mathrm{Y}$, et al.: Morbidity and medication in a large 
population of individuals with Down syndrome compared to the general population. Dev Med Child Neurol. 2016; 58(3): 246-54.

PubMed Abstract | Publisher Full Text | F1000 Recommendation

72. F Faraco G, Park L, Zhou P, et al.: Hypertension enhances $\mathbf{A} \beta$-induced neurovascular dysfunction, promotes $\beta$-secretase activity, and leads to amyloidogenic processing of APP. J Cereb Blood Flow Metab. 2015. PubMed Abstract | Publisher Full Text | F1000 Recommendation

73. F Thanopoulou K, Fragkouli A, Stylianopoulou F, et al:: Scavenger recepto class $\mathrm{B}$ type I (SR-BI) regulates perivascular macrophages and modifies amyloid pathology in an Alzheimer mouse model. Proc Natl Acad Sci U S A. 2010; 107(48): 20816-21.

PubMed Abstract | Publisher Full Text | Free Full Text | F1000 Recommendation
74. Tong XK, Nicolakakis N, Kocharyan A, et al:: Vascular remodeling versus amyloid beta-induced oxidative stress in the cerebrovascular dysfunctions associated with Alzheimer's disease. J Neurosci. 2005; 25(48): 11165-74.

PubMed Abstract | Publisher Full Text

75. Davis J, Xu F, Deane R, et al.: Early-onset and robust cerebral microvascular accumulation of amyloid beta-protein in transgenic mice expressing low levels of a vasculotropic Dutch/lowa mutant form of amyloid beta-protein precursor. J Biol Chem. 2004; 279(19): 20296-306. PubMed Abstract | Publisher Full Text

76. Remes AM, Finnilä S, Mononen $\mathrm{H}$, et al.: Hereditary dementia with intracerebral hemorrhages and cerebral amyloid angiopathy. Neurology. 2004; 63(2): 234-40. PubMed Abstract | Publisher Full Text 


\section{Open Peer Review}

\section{Current Peer Review Status:}

\section{Editorial Note on the Review Process}

Faculty Reviews are review articles written by the prestigious Members of Faculty Opinions. The articles are commissioned and peer reviewed before publication to ensure that the final, published version is comprehensive and accessible. The reviewers who approved the final version are listed with their names and affiliations.

\section{The reviewers who approved this article are:}

\section{Version 1}

\section{Juan Fortea}

Catalan Down Syndrome Foundation and Department of Neurology, Hospital de la Santa Creu i Sant Pau, Barcelona, Spain

Competing Interests: No competing interests were disclosed.

\section{Ira Lott}

Department of Pediatrics and Neurology, University of California, Irvine, CA, USA

Competing Interests: No competing interests were disclosed.

The benefits of publishing with F1000Research:

- Your article is published within days, with no editorial bias

- You can publish traditional articles, null/negative results, case reports, data notes and more

- The peer review process is transparent and collaborative

- Your article is indexed in PubMed after passing peer review

- Dedicated customer support at every stage

For pre-submission enquiries, contact research@f1000.com 